Gerión. Revista de Historia Antigua

ISSN: 0213-0181

\title{
A toponímia proto-histórica como ferramenta do arqueólogo? Comentários sobre uma relação problemática
}

\author{
Pedro Albuquerque ${ }^{1}$
}

Recibido: 17 de enero de 2018 / Aceptado: 5 de marzo de 2018

Resumo. Estudos recentes têm vindo a destacar a toponímia proto-histórica enquanto ferramenta para a interpretação do registo arqueológico, particularmente da sua filiação étnica. Este artigo discute, do ponto de vista metodológico, o uso anacrónico das informações da Linguística no discurso arqueológico, sobretudo no que diz respeito à formação, transmissão e cronologia destes topónimos, assumindo que são estudos realizados sobre línguas antigas desconhecidas. Estes aspectos levam a que a relação entre Arqueologia e Toponímia seja problemática, principalmente quando o objectivo é a análise de vestígios materiais de períodos mais recuados. Apresentam-se alguns casos que revelam estes problemas.

Palavras chave: Toponima pré-romana; Linguística; Arqueologia.

\section{[en] Protohistoric toponymy as a tool for the archaeologist? Comments on a problematic connection}

\begin{abstract}
Recent research gave some visibility to Protohistoric toponyms as tools for the interpretation of the archaeological record, particularly its ethnic identification. This paper discusses, discusses, from a point of view, the anachronistic use of data from Linguistics in the archaeological discourse, especially the formation, transmission and chronology of those toponyms created by unknown languages. This leads us to consider that the relationship established between Archaeology and Toponymy is problematic, especially when there is a remarkable chronological gap between the data they provide. We present some case studies that reveal these problems.
\end{abstract}

Keywords: Protohistoric Toponymy; Linguistics; Archaeology.

Sumario. 1. Introdução. 2. Apontamentos sobre a perspectiva linguística. 3. Transmissão, formação e interpretação dos nomes: exemplos e interrogações. 4. Um exemplo de toponímia "tartéssica": a série -ip(p)o. 5. Discussão: toponímia e registo arqueológico. 6. Referências bibliográficas.

Cómo citar: Albuquerque, P. (2018): A toponímia proto-histórica como ferramenta do arqueólogo? Comentários sobre uma relação problemática, en Gerión 36/1, 141-161.

1 FCT; Uniarq (Universidade de Lisboa); Universidad de Sevilla.

E-mail: albuquerque@us.es 


\section{Introdução}

O uso dos estudos linguísticos, em particular da toponímia proto-histórica peninsular, tem vindo a ganhar, nos últimos anos, um protagonismo interessante em várias publicações enquanto ferramenta de interpretação do registo arqueológico e, inclusivamente, da filiação étnica das comunidades que ocuparam os sítios conhecidos. Esta linha de argumentação, apesar do seu inegável interesse, é extremamente problemática e justifica a reflexão que aqui se apresenta sobre a chamada "toponímia tartéssica".

O presente texto não surge como um intento de testar, aceitar ou negar propostas de etimologia, mas, antes, de questionar e discutir a validade e alcance dos topónimos enquanto "indicadores étnicos" ou pontos de partida para a interpretação do registo arqueológico. ${ }^{2}$ Esta opção conduz a assinalar, com as limitações do signatário deste texto, as diversas propostas de interpretação de um mesmo nome de lugar, destacando a estreita relação que dita análise mantém com a especialização do linguista. ${ }^{3} \mathrm{Com}$ isto, pretende-se dar visibilidade a um aspecto que sobressai desta observação: a opção do arqueólogo recai, algumas vezes, sobre a proposta que mais se adequa aos interesses de uma ideia preconcebida. ${ }^{4} \mathrm{~A}$ isto junta-se ainda a constatação de que as reservas da investigação linguística são, por vezes, ignoradas nos discursos arqueológicos que a utilizam.

Aspectos como as circunstâncias e cronologia da transmissão destes nomes (sobretudo etnónimos, hidrónimos, e topónimos) devem ser considerados, de modo a obter uma visão mais abrangente dos problemas que envolvem este tipo de análise. É, portanto, de toda a utilidade começar por apresentar alguns dados sobre a história das investigações no âmbito da Linguística, de modo a identificar alguns problemas que serão debatidos. Depois, assinala-se o exemplo de alguns topónimos em -ip(p)o, com o objectivo de ilustrar a relação entre Toponímia e Arqueologia. Finalmente, um ponto de discussão, onde se expõem alguns aspectos da dita "relação problemática".

\section{Apontamentos sobre a perspectiva linguística}

A Linguística é, grosso modo, um produto do Romantismo e da ideia de individualidade de um povo (ou "raça") definida pela sua língua. A importância do idioma na consolidação das imagens românticas sobre o passado é inquestionável, a julgar pela formação de conceitos como "Indo-europeu" (IE) ou "Indo-germânico", defendidos,

\footnotetext{
Escacena 1992; Torres 2005; Almagro - Torres 2009; Almagro 2010.

O exemplo da discussão sobre o topónimo Malaca é particularmente interessante nesse sentido: Gesenius, seguido por Hübner, propôs uma origem fenícia partindo do hebraico Məla $(') k \bar{a}(h)$, "oficina"; Solá Solé identificou uma ligação com um nome líbio, com assimilação da primeira nasal; Humboldt relacionou Malaca com o basco mal-carra, "terreno escabroso" (Villar 2000, 306-307). Sanmartín $(1994,237)$ viu no topónimo uma assimilação da primeira nasal do nome líbio NK. Villar, por sua vez, propôs uma origem indo-europeia para *mal(Albuquerque 2014, 21).

4 Este problema foi também assinalado por Maluquer $(1969,1-2)$ relativamente às fontes: “[...] existe una peligrosa tendencia a seleccionar de las fuentes literarias sólo aquello que conviene a las deducciones de la investigación arqueológica". Schulten foi responsável por um processo inverso, ao procurar utilizar a Arqueologia para provar as suas ideias sobre as fontes.
} 
respectivamente, por Young (seguido por Bopp) e Klaproth. ${ }^{5} \mathrm{O}$ primeiro destes autores introduziu a comparação entre as línguas em termos morfológicos, marcando a afirmação desta disciplina como ciência autónoma, bem como uma ruptura face à simples identificação de similitudes fonéticas, comuns nos estudos do séc. XVIII ${ }^{6}$ ou nos textos antigos. ${ }^{7}$

A partir de 1821, Humboldt desenvolveu o modelo "basco-iberista" com base na nova metodologia, considerando que os Iberos eram uma entidade individualizada e unida por uma mesma língua, da qual descendia o Basco. ${ }^{8}$ Este modelo, inovador naquele momento, foi dominante até à primeira metade do séc. XX. ${ }^{9} \mathrm{~A}$ herança humboldtiana reflectiu-se nos trabalhos de Hübner, que matizou algumas das propostas do seu antecessor e desenvolveu outras com maior rigor. Schulten aproveitou, por sua vez, algumas ideias de Humboldt para tratar a toponímia meridional (séries -uba e -ip(p)o), defendendo origens grega e tirsena para alguns nomes peninsulares ${ }^{10}$

Os estudos de Meyer-Lubke, na primeira metade do séc. XX, representam o início da superação do modelo basco-iberista e da formulação de novas perspectivas que acabaram por defender outras origens para as línguas faladas na Península Ibérica, mais concordantes com programas de investigação nacionalistas. ${ }^{11} \mathrm{~A}$ consolidação desta ruptura manifestou-se na separação entre o "Tartéssico" e o "Ibérico". Neste contexto, a individualidade da série toponímica -ip $(p) o$ acabou por ser integrada por Gómez Moreno, juntamente com outras (-uba, -tuci, -ucci, -urci, -murgi e -ici), na primeira designação, construindo com isto a imagem de uma realidade onomástica própria de territórios meridionais, habitados pelos "Tartéssios".

Tovar foi profundamente influenciado por Gómez Moreno, ${ }^{12}$ mas manteve alguns aspectos do modelo de Humboldt. Apesar de reconhecer elementos de línguas celtas ou Indo-europeias entre os povos pré-romanos, Tovar identificou outros que não podiam ser enquadrados nestas designações. Para dar resposta a estas questões, defendeu a existência de dois grupos de origem de nomes: ibérica ou basca (il-, -urci e -uri) e tartéssica (-ipo, -ucci, -tucci). ${ }^{13}$ A sua perspectiva, do mesmo modo que a de Martínez Santa-Olalla, é um reflexo do pensamento de Kossinna. ${ }^{14}$ Estas investigações, enquadráveis na linha também seguida por Albertos, ${ }^{15}$ configuraram um conjunto de contributos destinados a "comprobar la gran importancia del factor indoario en la Hispania prerromana, y siempre como grupo dirigente". ${ }^{16}$

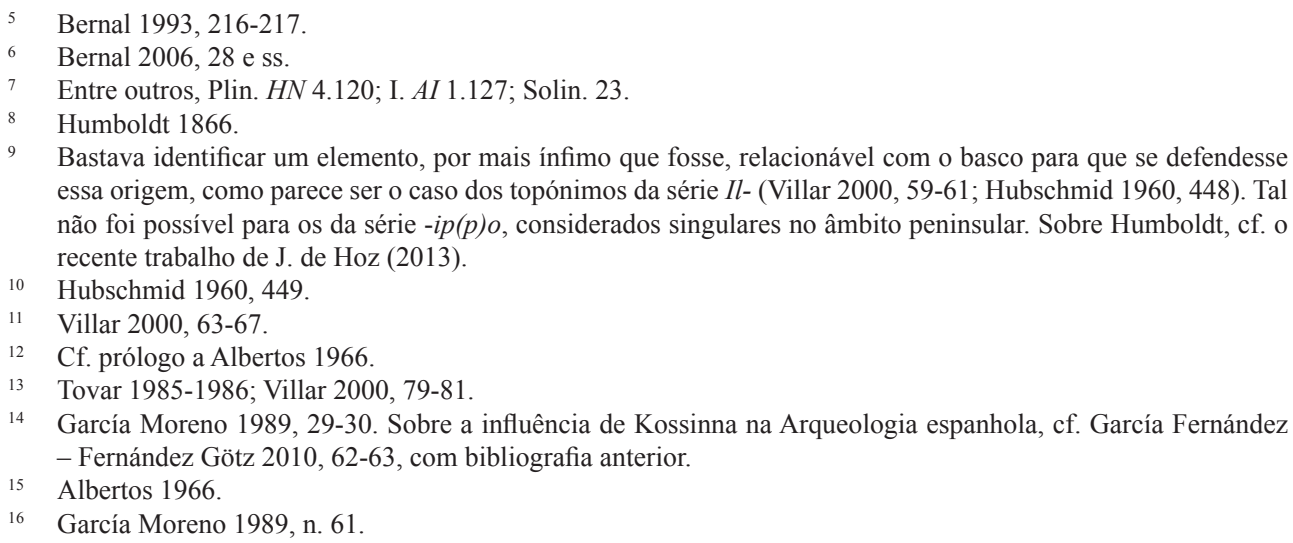


Untermann, por seu turno, foi responsável pela sistematização da toponímia peninsular, assinalando a concentração dos topónimos das séries -ip(p)o e -uba ao longo do Guadalquivir. ${ }^{17}$ Esta distribuição foi determinante para a utilização do conceito de "toponímia tartéssica", como veremos.

O mesmo critério não foi, porém, aplicado na designação da "escrita tartéssica" identificada nas estelas epigrafadas que se concentram, maioritariamente, no Sul de Portugal. ${ }^{18}$ Apesar das várias sugestões de filiação $\mathrm{IE}^{19}$ e céltica ${ }^{20}$ para a língua vertida nas estelas, a investigação ainda não vislumbrou qualquer relação evidente com os topónimos ditos "tartéssicos". ${ }^{21}$ Discute-se também, neste contexto, a origem do signário das estelas ${ }^{22}$ e de grafitos como o de Abul, ${ }^{23}$ bem como a cronologia daquelas manifestações. ${ }^{24}$ A Arqueologia pode fornecer leituras e informações sobre esta última questão, mas não dispõe de meios suficientes para negar ou aceitar as posições mantidas nas outras discussões, que pertencem a outros âmbitos científicos. ${ }^{25}$

Este percurso, sumariamente apresentado nestas linhas, pretende assinalar algumas vertentes da investigação linguística, sobretudo no que diz respeito às antigas línguas peninsulares, remetendo para a bibliografia o aprofundamento das questões colocadas. Assinala, igualmente, uma contradição que não deixa de ser interessante: a utilização de uma mesma designação para uma língua percebida através da toponímia e para um sistema de escrita em áreas geográficas diferentes. Podemos dizer que estamos, nestes casos, perante convenções destinadas a apreender uma realidade à qual só muito parcialmente conseguimos aceder e que resultam do reconhecimento de nomes numa área geográfica identificada (também convencionalmente) com o "mundo tartéssico": o Guadalquivir. Note-se que esta tendência de "regionalizar" as línguas foi recentemente criticada por Villar, na medida em que a atribuição dos termos a um contexto linguístico depende mais da área onde foram identificados ("celta", "báltica", etc.) do que da sua estrutura. ${ }^{26}$

17 Untermann 1962; cf. Villar 2000, 72.

18 O uso da designação "tartéssica" para este sistema de escrita e para a língua aí representada é extremamente problemático, o que justifica a cada vez mais frequente adopção do conceito de "escrita do Sudoeste" (Valério 2014, 441-442; Correa 2005, 289 e ss.; 2009). De Hoz, por seu turno, defende que a língua do Sudoeste e a "tartéssica" são diferentes (1996, 200-201).

19 Wikander propôs esta relação da identificação de uma desinência "tartéssica" (-be) com o sufixo -bhi (IE), segundo Tovar (1969, 343-345; cf. Wikander 1966). Tovar (1969, 343-345) assinala uma proposta, apresentada anteriormente, por Wikander (1966).

20 Entre outros, Correa 1989, passim; 1996, 245 e ss., e 2005; De Hoz 1995, 591-593; Koch 2009 e 2010; Valério 2014, 440 e ss.

${ }_{21}$ Para Plínio-o-Velho (HN 3.13): "Celticos a Celtiberis ex Lusitania advenisse manifestum est sacris, lingua, oppidorum vocabulis quae cognominibus in Baetica distinguntur" ("É evidente pela religião, pela língua e pelos nomes das cidades - que na Bética se distinguem pelos cognomes- que os célticos, descendentes dos Celtiberos, vieram da Lusitânia”; trad. Guerra 1995).

22 Valério, num artigo recente, afirma, relativamente à escrita do Sudoeste "their language cannot be identified and the identity of their writing system is uncertain. Although some were found in locations that make it tempting to connect them to the script of the SW stelae, this cannot be done with safety" (2014, 443). Cf. De Hoz 1996, passim.

23 Sznycer 2000; Correa 2011.

24 Correa 1996, 239-242; De Hoz 1996, 197-199; Villar 2000, 81; Arruda 2001; Guerra 2010. Não se consideram aqui as propostas de tradução, uma vez que excedem os propósitos deste trabalho, para além de não acrescentarem nenhum dado relevante à discussão aqui mantida.

25 Note-se que uma das conclusões do estudo do grafito identificado em Abul A (Sznycer 2000) corrobora uma interpretação do sítio como feitoria, defendida ainda antes das escavações arqueológicas (Albuquerque 2014, 209 e ss., com bibliografia e discussão sobre o sítio).

26 Villar 2014, 23 e ss. 


\section{Transmissão, formação e interpretação dos nomes: exemplos e interrogações}

Una lengua reconstruida es tan sólo el resultado de una larga cadena de deducciones hipotéticas, cuyo grado de aproximación a la realidad depende para empezar de la veracidad de la hipótesis en que se asienta (...). ${ }^{27}$

É necessário considerar, antes de mais, as fontes disponíveis, bem como os seus problemas, para levar a efeito uma leitura rigorosa da transmissão dos nomes de lugar, de rios, comunidades ou regiões e, a partir daí, valorizar devidamente as informações numa perspectiva crítica e problematizar as questões de toponímia. Vejamos algumas situações que exemplificam estas afirmações.

O primeiro é $A \lambda u ́ \beta \eta s$, um topónimo transmitido na Ilíada ${ }^{28}$ e que foi integrado por F. Villar na série -uba/-oba, relacionando-se, por seu turno, com outros nomes peninsulares (Onuba, Ossonoba, Corduba, etc.) com a transcrição Alibe.$^{29}$ Partindo, justamente, da informação homérica, este investigador defendeu que "a principios del I milenio a.C. el pueblo de los hidrónimos $u b a$ estaba asentado en la desembocadura del Guadalquivir", ${ }^{30}$ e que $u b a$ significava "água" (rio Maenuba em Plinio). ${ }^{31}$

Gangutia, por seu turno, transcreveu, tal como Crespo Güemes, ${ }^{32}$ o topónimo homérico como Álibe, relacionando-o com os "descubrimientos tardo-micénicos en el curso medio del Guadalquivir y de cerámica griega en Huelva". ${ }^{33}$

De facto, outras fontes apresentam A $\lambda \hat{\jmath} \beta \eta$ como um orónimo grego que seria na sua origem um nome "bárbaro" (Calpe), apresentando também uma "variante con metátesis consonântica" (A $\beta \hat{\lambda} \lambda \eta)$, e que representaria, como tal, a penha setentrional do Estreito de Gibraltar. Trata-se, possivelmente, de uma tentativa de identificação tardia do nome homérico num lugar da Península Ibérica. ${ }^{34}$

Este exemplo exprime com alguma clareza os problemas da recepção de informações de outras disciplinas. Gangutia defende explicitamente a cronologia alta proposta para os Poemas Homéricos ${ }^{35}$ mas estabelece uma relação muito questionável entre Il. 2.857 e os citados materiais arqueológicos. Prudentemente, Villar não enveredou pelo caminho arqueológico, mas não é explícito no seu posicionamento perante a fonte da qual retirou aquela informação, assumindo uma cronologia antiga e o

27 Villar 2014, 16.

28 Hom. Il. 2.857.

29 Villar 2000, 122, 438-439. Sobre A $\lambda \hat{\beta}\rceil \varsigma$, cf. Torres 2002, 324-325, com a transcrição Aluba. O nome foi assinalado nos THA (IIA, 20.II) como uma referência a Anacreonte no texto de Dionísio Periegeta (v. 332), mas esta atribuição não é segura (Gangutia, en Mangas - Plácido 1998, 127). Esta autora, aliás, assinalou o etnónimo A $\lambda u ́ \beta \alpha v \tau o \varsigma$ (Gangutia, en Mangas - Plácido 1998, 10; Od. 24, 34). Estêvão de Bizâncio transmitiu também este nome, relacionando-o com AA $\lambda \hat{\beta} \alpha \alpha_{\varsigma}$ (s.v.) e citando também Homero. Não deve confundir-se este nome com 'A $\lambda \hat{\beta}\rceil \varsigma$, também transmitido pelo gramático bizantino.

30 Villar 2000, 439.

31 Plin. $H N$ 3.11. Esta desinência foi identificada noutras áreas europeias e interpretada como uma homofonia ou variante do "Celta" *ab- (Villar 2000, 162-163; Albuquerque 2014, II, fig. 3.2a) que, num determinado momento, terá surgido no Guadalquivir.

32 Gangutia, en Mangas - Plácido 1998, 8, n. 5; Crespo 2006.

33 A autora acrescentou, no entanto, o nome $A \lambda \hat{\beta} \beta \alpha v \tau o \zeta(O d .24 .304)$, assinalando a partícula -nt-, identificável, p. ex., no nome de Argantónio (Gangutia, en Mangas - Plácido 1998, 10). Propôs uma correcção do texto posterior de Apolodoro (2.5.10) para justificar esta proposta. De acordo com este texto, Héracles "llega a Eritea y acampa $\dot{\varepsilon} v$ A $(\lambda v) \beta \alpha \nu \tau 1$, en el monte Abante". Sobre a relação do nome próprio "Argantónio" com o Monte Argantónio na Bitínia, cf. Rodríguez Adrados 2000, 11; Moret 2006, 52.

34 Correa 2016, 193 e referências a fontes.

35 West 1988. 
conhecimento, por parte do(s) autor(es) da Ilíada, da Península Ibérica. ${ }^{36}$ Acabou, porém, por assinalar que o conjunto dos nomes em -uba, dada a constatação da sua dispersão, pode reflectir a existência de similitudes fonéticas de nomes que podem não pertencer ao mesmo âmbito linguístico. ${ }^{37}$

Podemos afirmar, portanto, que a cronologia da transmissão pode não corresponder à da formação do topónimo. Outros nomes em -uba/-oba, como Maıvó $\beta \omega \rho \alpha$, podem ter sido transmitidos no séc. VI a.C., se considerarmos válida a informação de Hecateu, ${ }^{38}$ relacionando-se com as posteriores referências a Maenoba ${ }^{39}$ e Mólvo $\beta \alpha .^{40}$

O segundo exemplo diz respeito ao modo como um topónimo serviu de ponto de partida para identificar uma ocupação "indígena", na qual foi implantado um bairro e um santuário "fenícios": Caura, actual Coria del Río. Esta análise é coerente com as propostas de Escacena sobre a importância dos topónimos auto-impostos na definição da origem de uma comunidade. ${ }^{41} \mathrm{~A}$ interpretação do indigenismo do sítio deveu-se a um estudo de A. Padilla, que identificou uma filiação IE para o topónimo baseando-se, exclusivamente, nos trabalhos de Albertos Firmat. ${ }^{42} \mathrm{O}$ reconhecimento de uma aparente raiz $* \mathrm{Keu}$-, identificada em antropónimos trácios e galos, ou mesmo em topónimos como Caurum (Cáceres), foi suficiente para que se estabelecesse uma ligação com um suposto substrato "pré-celta". ${ }^{43}$ dadas as similitudes que a Andaluzia "pré-colonial" apresentava em relação ao "Bronze Atlântico". ${ }^{4}$

Defendeu-se, por conseguinte, uma cronologia centrada no séc. IX a.C. para a formação do nome de Caura, mas a transmissão é mais tardia, i.e., a partir de finais do séc. III a.C., nas legendas das moedas e, posteriormente, no texto de Plínio. ${ }^{45} \mathrm{~A}$. Padilla adoptou uma postura bastante prudente face a esta situação, questionando se o topónimo foi atribuído, de facto, pelos fundadores do sítio e "si se trataba de gentes de habla indoeuropea preceltas o celtas". ${ }^{46}$ Para Escacena, por seu turno, a origem do nome está nas "poblaciones que a finales de la Edad del Bronce reocuparon el cerro", ${ }^{47}$ embora se admita que dita ocupação não está ainda representada como seria desejável.

36 Cf. Correa 2016, 193.

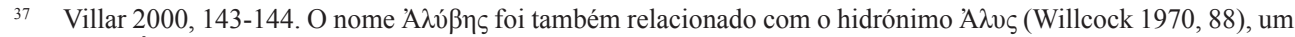
rio da Ásia Menor várias vezes mencionado nas fontes (A. Pers. 865; Hdt. 1.6.1; 1, 75; 5.52.2: cf. Marek 2004), bem como com o topónimo X $\alpha \lambda v ́ \beta \eta \varsigma$ (Str. 13.3; St. Byz. s.v. X $\alpha \lambda v ́ \beta \eta \varsigma=F G r H 1$, fr. 203), assinalado por Heródoto no contexto das conquistas de Creso a Oeste do A $\lambda v \varsigma$ (Hdt. 1.28.1).

38 St. Byz. s.v. M $\alpha$ vó $\beta \omega \rho \alpha$.

39 Mela 2. 94; Plin. HN 3.8.11; De Hoz, en Torres 2002, 324.

40 Ptol. Geog. 2.4.7.

41 Escacena 1992, 335.

42 Padilla 1993; Albertos 1966.

43 Albertos 1966, 83; Padilla 1993, 63-64.

44 A posterior ocupação "fenícia” foi intuída por Belén Deamos (1993) numa importante reflexão sobre uma passagem de Avieno que refere o Mons Cassius (O.M. 249), associando-o a Baal Saphon, e alguns achados isolados; esta ideia acabou por ser confirmada em escavações posteriores, que detectaram a existência de um santuário (Escacena - Izquierdo 2001, 126). Trata-se, neste caso, de uma interpretação toponímica baseada nas fontes, sem qualquer pretensão de apresentar uma relação com dados linguísticos.

45 Chaves 1993; Plin. HN 3.11.

46 Padilla 1993, 63. Mais tarde, Fernández Götz (2007) apresentou uma reflexão historiográfica sobre esta questão, onde defende (tal como Ruiz Zapatero), a existência de um "mosaico" de influências que não são atribuídas, necessariamente, a um "grupo étnico" com o nome de "Celtas".

47 Escacena 2001, 79. 
O estudo de F. Villar apontou a bússola para outra direcção. Reconhece a existência de topónimos $(\mathrm{K} \alpha \lambda \hat{\beta} \beta \eta)$ e antropónimos trácios, tal como vimos, mas identifica como derivados de uma mesma origem nomes em Cav-, Cab-e, claro, Cau-: Cauros (ilha do Egeu), Caburriates (povo ligur), Cavorae (fonte na Mesopotâmia), etc. ${ }^{48}$ As semelhanças e as relações não se esgotam, certamente, nestas reflexões, e é por isso que importa assinalar o desafio que a cronologia da formação e transmissão de um nome coloca à investigação. Muitos deles são transmitidos em épocas tardias, como aliás foi apontado por De Hoz. ${ }^{49}$ Por outro lado, pode tratar-se de uma latinização de um nome indígena. ${ }^{50}$

Estes problemas são ainda mais evidentes quando se desconhece a língua que deu origem a estes nomes. ${ }^{51}$ Sem esse conhecimento mínimo, é problemático definir uma cronologia relativamente precisa para a formação da (convencionalmente) chamada "toponímia tartéssica". ${ }^{52}$ Veremos no próximo capítulo como esta designação foi determinante em vários estudos arqueológicos posteriores que procuraram, através do registo arqueológico e destes dados toponímicos, defender uma "colonização tartéssica".

Por outro lado, os topónimos parecem ser menos permeáveis à mudança que os antropónimos, mantendo-se muitas vezes independentes dos processos históricos e das mudanças de poder. ${ }^{53}$ Tal não exclui pequenas ou grandes mudanças, ou mesmo substituição de nomes quando uma língua se sobrepõe à outra. ${ }^{54}$ Também não exclui casos em que os topónimos são trasladados sem que os seus portadores conheçam o seu significado original, o que é particularmente visível em nomes impostos pelos conquistadores ibéricos no continente americano, ou mesmo em nomes híbridos e reinterpretações. ${ }^{55}$

Nesta perspectiva, um contexto social, cultural e histórico pode deixar a sua marca num nome de lugar a partir do momento em que este é (re)ocupado, criando condições para estabelecer uma proposta de cronologia para a formação de topónimos, hidrónimos ou corónimos. ${ }^{56}$ Os mencionados nomes levados pelos conquistadores reflectem uma circunstância histórica perfeitamente identificada e não oferecem grandes dúvidas, do mesmo modo que a inclusão de termos como "iglesia" ou nomes de santos noutras ocasiões. Esta leitura, evidentemente, não se aplica com o mesmo rigor a línguas desconhecidas que deram origem, num determinado momento, a um topónimo pré-romano, mais ainda quando não é possível definir uma ligação inequívoca entre essa língua e um grupo humano. Por outro lado, nem sempre um nome é atribuído a um lugar a partir do momento em que é ocupado, sobretudo se alguma parte do nome diz respeito a um acidente geográfico. ${ }^{57}$

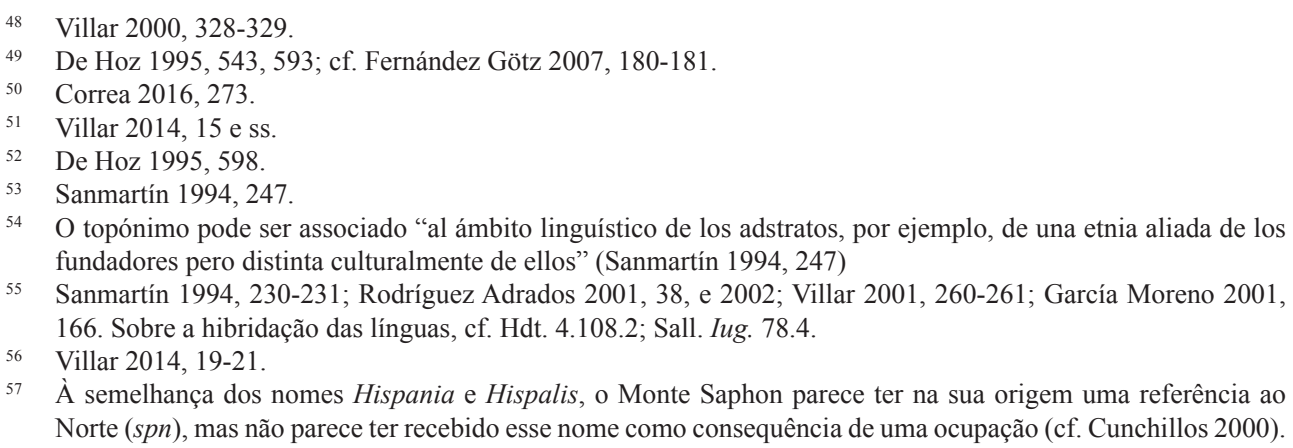


Noutros casos, o topónimo pode ser transmitido numa fonte, como resultado de uma interpretação da paisagem ou mesmo das comunidades representadas. Atenden-

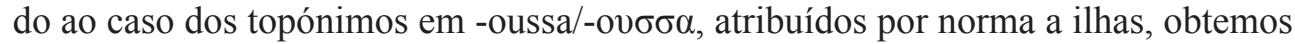
um exemplo expressivo das considerações que se tecem em torno das informações literárias. Estes nomes sustentaram propostas sobre uma antiga frequentação eubóica e foram também analisados a partir dos já mencionados achados micénicos. ${ }^{58}$ Schulten, por seu turno, afirmou que a presença destes topónimos "revela, sin duda, el paso de los Jonios y de los Focenses". ${ }^{59}$ Pierre Moret propôs uma cronologia anterior ao séc. VI a.C., mas parece arriscado estender esta interpretação aos topónimos relacionados com a Península Ibérica. ${ }^{60}$

De facto, alguns destes nomes foram referidos por Hecateu, mas o seu interesse pela botânica ${ }^{61}$ pode ter justificado designações como Oivoṽ $\sigma \sigma \alpha l$ (Oinoussai, "ilha das vinhas") ou Mínov $\sigma \sigma \alpha$ (Meloussa, "ilha das maçãs"), transmitidos mais tarde por Estêvão de Bizâncio. ${ }^{62}$ Segundo este autor, na Periegesis de Hecateu encontrava-

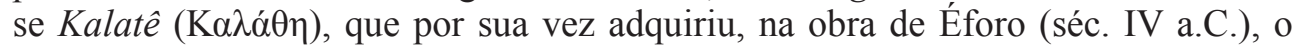

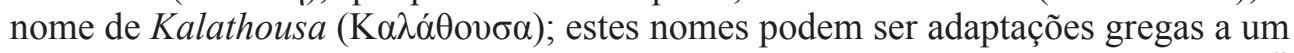
topónimo de origem oriental (Cart-), por sua vez relacionado com Cerro del Prado. ${ }^{63}$ Integram-se ainda nesta situação outros nomes que foram traduzidos, trasladados ou transcritos a partir da língua grega. ${ }^{64}$ É possível verificar que os nomes podem variar de autor para autor, ${ }^{65}$ o que aliás é muito comum nas primeiras descrições de África e das comunidades africanas.

Spal ou Hispalis, actual Sevilha, é também um exemplo útil para esta discussão, ${ }^{66}$ do mesmo modo que o topónimo Balsa. O primeiro permitiu defender que tanto El Carambolo como Hispalis eram fundações fenícias. ${ }^{67}$ Sanmartín defendeu que o topónimo era um exemplo de falta de plausibilidade pragmática (i.e., o nome tem um significado que lhe dá sentido nas circunstâncias em que é utilizado), uma vez que a etimologia seria explicada através da presença de /'y/(península, ilha ou costa), que por sua vez era incompatível com a localização interior que se pensava para a cidade andaluza.$^{68}$ Os estudos paleogeográficos acabaram por conferir, pouco tempo depois, essa plausibilidade ao topónimo, uma vez que definiram os contornos um braço de mar que chegava até esta área em época proto-histórica. ${ }^{69}$ Por seu turno, Correa afirmou que Hispalis era um nome híbrido entre uma forma "tartéssica" His- à qual se juntou o teónimo Baal, posteriormente latinizado em -pal, designando uma "ilha de Baal". ${ }^{70}$

\footnotetext{
58 García y Bellido 1948, I.66-78; García Alonso 1996, 105-106; Gangutia, en Mangas - Plácido 1998, 8, n. 5; Moret 2006, 42-46; Álvarez 2007, 480-481.

59 Schulten 1945, 90.

60 Moret 2006.

61 Plin. HN 1.18, en Gangutia, en Mangas - Plácido 1999, n. 17; Moret 2006, 48.

62 A formação de topónimos ou corónimos nestas circunstâncias foi também frequente nas descrições da costa africana por parte dos europeus. Nomes como Costa do Marfim, Costa do Ouro ou Costa dos Escravos são exemplos de como uma determinada característica do lugar ou da região inspira a atribuição de um nome por parte de uma entidade externa (para um estudo da toponímia portuguesa na costa africana, v. Mota 1950).

63 Ferrer - Jiménez 2015.

64 Rodríguez Adrados 2000 e 2001; Moret 2006, tab. 2.

65 Plin. HN 4.120.

66 Díaz 1982, 19-20; Lipínski 1984, 100; Correa 2016, 324-326.

67 Belén - Escacena 1997; Correa 2000.

68 Sanmartín 1994, 239.

69 Arteaga et alii 1995; Escacena 2001, 74-76.

70 Correa 2000
} 
O nome de Baal foi recentemente trazido à colação para a análise da ocupação de Balsa. Antes disso, a discussão sobre o topónimo surgiu na obra de Humboldt que, como seria de esperar, relacionou o nome com uma forma basca (balsatu, "reunir"); ${ }^{71}$ foi seguido por Tovar, que introduziu uma leitura baseada em baldar ("assembleia") e noutros termos que remetem para uma ideia de agrupamento, bem como na identificação de outra Balsa na Sardenha. ${ }^{72}$ Outros sentidos concordariam com a ideia de "água", "pântano" ou "charco". ${ }^{73}$ A análise de Villar incidiu sobre um âmbito IE, assinalando concordâncias na Península Ibérica, sem qualquer correspondência africana ou asiática. ${ }^{74}$

A identificação de um santuário fenício conduziu os investigadores de Tavira à elaboração de uma nova proposta, baseada numa suposta identificação do teónimo Baal, à semelhança do que Correa propusera para Hispalis, sem contudo sustentar esta hipótese num estudo etimológico rigoroso.$^{75}$ Sobressai nesta argumentação o nome Balsamen (lat.) ou Baal-Shamen ("Senhor do céu"). ${ }^{76}$

Como se fez notar, não é objectivo deste trabalho afirmar ou desmentir a validade linguística destas propostas. Porém, é útil assinalar alguns padrões de utilização de teónimos em nomes de lugar. Este fenómeno parece ser frequente no Próximo Oriente (Astarot, Betel, Baal-Gad), registando-se nomes formados com Baal nos textos neo-assírios. ${ }^{77}$ Chama, porém, a atenção o facto de estes topónimos apresentarem significados relacionados com uma particularidade desse "Senhor" ou com o próprio lugar. Disto são exemplos nomes como Baal-Gad ou "Senhor da Fortuna", ${ }^{78}$ Baal Hermon ou "Senhor do Monte Hermon" ${ }^{79}$ e Baal-Meon ou Bet-Baal-Meon, ${ }^{80}$ que indicia a presença de um edifício de culto dedicado a Baal. ${ }^{81}$ Atendendo a estes exemplos, sobejam razões para ter algumas reservas em relação ao uso de um teónimo ou de um epíteto de Baal na formação do topónimo Balsa, na falta de propostas que permitam interpretar a componente $-s a$, e que confirmem a existência de um padrão que não parece ter paralelos orientais.

Os topónimos, apesar de se reconhecer que são menos permeáveis a mudanças, não deixam de sofrer algumas alterações ou adaptações, revelando a extrema dependência que a investigação tem em relação às fontes que os transmitem e em numismas mais tardios. A forma de um nome depende da língua do grupo que a transmite, o que é particularmente revelador em duas passagens de Plínio-o-Velho. Na primeira, ${ }^{82} \mathrm{o}$ autor afirmou que existiam 165 oppida distribuídos pelos conventos jurídicos da Bética ( $\mathrm{Ga}$ -

\footnotetext{
71 Humboldt 1866, 40.

72 Bertoldi, en Tovar 1970, 8.

73 Coromines 1990, s.v. Balsa; Machado 1977, s.v. Balsa.

74 Villar 2000, 288, 296 e ss.

75 Maia - Silva 2004, 174 e ss. Mantas $(1997,291)$ propôs, igualmente, uma etimologia oriental. É comum ver nas publicações sobre Tavira, onde se menciona a questão do topónimo, uma citação ao trabalho de Correa (2000). Na última nota do trabalho, o autor afirmou, relativamente a Hispalis, que "no se trataría de una hipótesis aislada, pues algo similar cabe decir de Bal-sa (ciudad turdetana, según Ptolomeo), si bien con el teónimo en primer lugar", referindo a clara presença fenícia com base numa informação transmitida por Maia, manifestando, aliás, algumas reservas a este respeito, com a prudência que caracteriza o seu trabalho (Correa 2000, 190)

76 Röllig 1999.

77 A cronologia destes topónimos em Canaã é discutível, apontando-se para a Idade do Ferro (Na'aman 1999).

$78 \quad$ Js. $11.17 ; 12.7 ; 13.5$.

79 Dt. 3.8, "os sidónios dão ao Hermon o nome de Sírion e os amorreus chamam-lhe Senir".

80 Js. 13.17

${ }_{81}$ Em Nm. 32.38, assinala-se que os filhos de Gad, que dominaram, segundo o texto, os reinos de Seon e Og (Nm. 32.33), reconstruíram várias cidades, entre elas Baal-Meon, mudando o nome desta última (Na'aman 1999).

82 Plin. $H N$ 3.7.
} 
des, Corduba, Astigi e Hispalis), dos quais destacou aqueles que eram digna memoratu (dignos de menção) e latio sermone dicto facilia (fáceis de enunciar em língua latina). ${ }^{83} \mathrm{Na}$ segunda, apontou alguns nomes para as ilhas gaditanas, que variavam de acordo com o autor ou comunidade que os transmitia. ${ }^{84}$

Este panorama permite afirmar que a construção de um discurso arqueológico baseado na toponímia não está isenta de problemas, sobretudo quando se estuda um período muito anterior ao da transmissão desses mesmos nomes. Esta afirmação é ainda mais taxativa no caso dos etnónimos, uma vez que muitas vezes são construções elaboradas pelo olhar externo sem qualquer relação evidente com a comunidade representada. Este tema apresenta problemas semelhantes, mas não terá agora o desenvolvimento que merece. ${ }^{85}$

Os exemplos que vimos até agora revelam: (a) a utilização de informações dos Poemas Homéricos para enquadrar uma análise dos topónimos em -uba/-oba e para

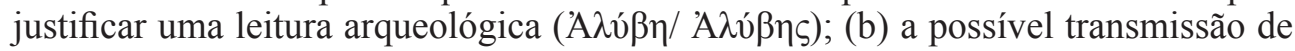
nomes criados, exclusivamente, no ambiente do observador para apreender uma realidade geográfica distante (topónimos em -oussa?); (c) a interpretação etimológica de um nome que permitiu conferir a uma cidade o "estatuto" de "fundação fenícia" (Spal), num caso, e "indígena" no outro (Caura), determinando a leitura dos processos de interacção e integração; (d) num processo inverso ao anterior, topónimos interpretados a partir dos vestígios arqueológicos $(\mathrm{Balsa})$. Estas situações têm em comum o facto de serem leituras que procuram relacionar as conclusões elaboradas num contexto científico com outros dados que não pertencem ao seu âmbito de estudo, criando uma relação artificial que se destina a provar uma ideia preconcebida.

Estes processos adquirem na "toponímia tartéssica" uma visibilidade extraordinária, sobretudo pelo modo como revelam alguns dos problemas que foram apontados ao longo destas linhas. Entre os problemas está, obviamente, a relação que se estabelece entre a manifestação toponímica de uma língua desconhecida e a interpretação da filiação "étnica" do registo arqueológico. Esta relação é particularmente evidente nas considerações tecidas em torno dos topónimos da série -ip(p)o, como veremos de seguida.

\section{Um exemplo de toponímia "tartéssica": a série -ip(p)o}

A designação de uma "toponímia tartéssica" é indissociável da discussão sobre o indigenismo de Tartessos e a sua génese no Bronze Final. ${ }^{86}$ Não seria coerente desenvolver aqui esta questão, sobretudo porque implica uma reflexão mais extensa do que aquela que pode ser exposta, ${ }^{87}$ mas veremos o efeito desta perspectiva na utiliza-

83 Note-se que, segundo Correa, -pal é já o resultado de uma latinização.

${ }^{84}$ Plin. HN 4.120: "Por la parte por donde mira a Hispania, a cien pasos más o menos, hay otra isla de mil pasos de largo y otros mil de ancho, en la que en su tiempo estuvo la población de Gades. Éforo y Filístides la llaman Eritea, Timeo y Sileno Afrodisíade, los naturales de la zona la denominan Isla de Juno. Timeo dice que a la mayor la solían llamar Cotinusa en su lengua; los nuestros la llaman Tartesos, los púnicos Gadir, que en lengua púnica significa 'recinto"” (trad. Fontán et alii 2008).

85 Cf. Albuquerque 2014, 55 e ss.

86 Referindo-se a os antropónimos, Torres $(2002,323)$ salientou que “(...) la información que proporcionan estos nombres personales pertenece (...) a época imperial romana y sólo podrían utilizarse para definir el área lingüística tartésica si se pudiese probar que representan una continuidad respecto a una situación muy anterior: el Bronce Final y el periodo orientalizante tartésico".

87 Cf. Álvarez 2005; Albuquerque 2013 e 2014, 93-148. 
ção dos dados toponímicos peninsulares para a explicação do registo arqueológico nos sítios que coincidem com estas séries. Antes disso, é importante recordar os contornos desta interessante discussão.

Os topónimos da série -ip $(p) o$ foram identificados em duas áreas diferentes: a primeira (nuclear), concentra-se no Guadalquivir; a segunda (de expansão), identifica-se até ao Tejo e afluentes ${ }^{88}$ motivando um interessante debate sobre a sua singularidade e distribuição na Península Ibérica a partir de Humboldt. ${ }^{89}$ Este autor partiu da análise etimológica de ï $\pi$ os (hippos, cavalo), bem como de representações de cavalos em várias moedas hispânicas. ${ }^{90}$ A presença deste elemento tinha já inspirado dúvidas a Aristóteles, quando refere o exemplo do nome próprio Kállipos como uma palavra que carece de sentido. ${ }^{91}$

As semelhanças fonéticas com outros nomes da Anatólia e África, ${ }^{92}$ ou mesmo

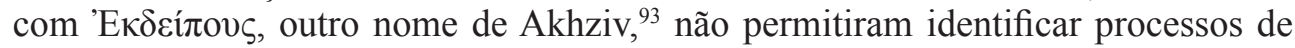
formação semelhantes aos casos peninsulares, conduzindo autores como Meyer -Lübke a defenderem a existência de um substrato indígena mais antigo.$^{94} \mathrm{~A}$ partir daí, foi um pequeno passo para que Gómez Moreno afirmasse que eram nomes "tartéssicos" (também indígenas), criando as condições necessárias para interpretar esta distribuição como sintoma da presença de tartéssios nestes lugares. ${ }^{95}$

Johannes Hubschmid, numa reflexão sobre a toponímia pré-romana, salientou que estes nomes fazem "pensar en un pueblo de origen desconocido", referindo alguns trabalhos anteriores que incidiram sobre a interpretação desta série. ${ }^{96}$ Trombetti valorizou a componente - $i$-, à qual se acrescentaria um - $p$ - seguido de vogal (- $p a$, -po). ${ }^{97}$ Bertoldi, por seu turno, identificou correspondências em África, propondo uma origem fenícia, ${ }^{98}$ enquanto que Pellegrin defendeu que os nomes que integram i $\pi \pi 0 v$ correspondem à área de influência cartaginesa. Antes disso, Gesenius defendera que o nome era um derivado do hebraico iafeh ("ser bonito"), enquanto que, para Movers, corresponderia a uma "fortaleza". ${ }^{99}$ Nesta leitura, "ipp-ôn teria uma tradução de "pequeno nariz" ou "língua de terra proeminente" com origem no proto-semi-

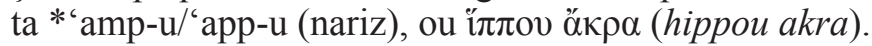

Em 1952, Laroche identificou alguns topónimos em ip (p) a nos arquivos hititas, ${ }^{100}$ aos quais seria possível acrescentar Borsippa, identificado em textos babilónicos, assírios e acádicos. ${ }^{101}$ Esta discussão deve, não obstante o seu interesse, ser mantida

\footnotetext{
88 Untermann 1962, mapa 16; Villar 2000, 111.

89 Faust 1976, 167; Villar 1999, 694; García Moreno 2001, 161.

90 Humboldt 1866, 59; Villar 2000, 62. Para Chantraine (1968), o termo grego apresenta, por sua vez, "singularités inexpliquées", nomeadamente a aspiração da vogal inicial (Chantraine 1968, s.v. ï $\pi$ tos, para a etimologia e termos relacionados) e tem uma origem "indo-europeia" (sic).

91 "Nombre, pues, es un sonido significativo por convención $\sin <$ indicar $>$ tiempo, y ninguna de cuyas partes es significativa por separado: en efecto, en Kállippos, ippos no significa nada por sí mismo, como < si ocurre> en el enunciado kalòs híppos (belo cavalo)" (Int. 16a, 19-21; trad. Candel Sanmartín 2007).

92 Villar 2000, 107 e ss.

93 Hekdeipous: I. AJ 5.85.

94 Villar 2000, 67; García Moreno 2001, 162.

95 Villar 1999, 707-714; 2000, 68-69; García Moreno 2001, 162; Torres 2002, 324.

96 Hubschmid 1960, 481-482.

97 Hubschmid 1960, 482.

98 Serra 1955, 812.

99 Pellegrin 1949, 125-126.

100 Hubschmid 1960, 483; cf. Villar 1999, 696-698, e 2000, 109 e n. 90-91; García Moreno 2001, 162.

101 Pritchard 1969, 306 (babilónicos); 277, 303, 535 (assírios); 332 (acádicos).
} 
no âmbito da Linguística, de modo a procurar explicar as semelhanças (que podem parecer evidentes para um receptor não especializado) com outros nomes hititas. ${ }^{102}$

Para Villar, esta aparente homogeneidade etimológica do conjunto hispano pode ser duvidosa, dificultando uma individualização categórica. ${ }^{103} \mathrm{O}$ facto de não ser possível atribuir uma cronologia precisa para a formação destes nomes anula qualquer hipótese de se optar por uma explicação histórica ou arqueológica suficientemente convincente para este fenómeno. ${ }^{104}$ Embora se registem casos de duplicação de nomes cujo significado original é desconhecido, ${ }^{105}$ é possível analisar as componentes do topónimo, de modo a propor interpretações viáveis de plausibilidade pragmática (cf. supra). Nesse sentido, partindo do que foi dito em relação a possíveis "traduções" destes topónimos, acrescentar-se -ia a proposta de Untermann, que defendeu que -ip( $p)$ o poderia significar "cidade". ${ }^{106}$

Que dizer, neste sentido, do hidrónimo Callipos? O antigo nome do rio Sado gerou uma interessante discussão sobre a relação que poderia manter com um topónimo (Cantnipo) supostamente identificado num numisma de Alcácer. ${ }^{107}$ Pensou-se, com isto, que o

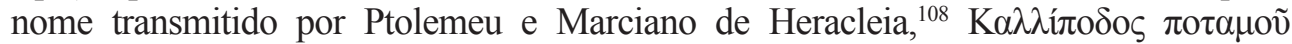
$\dot{\varepsilon} \kappa \beta$ o $\lambda \alpha i$, estaria corrompido. No entanto, esta posição acabou por ser revista devido à atribuição daquela inscrição à escrita do SW, resultando na leitura Beuibum, com uma forma latina Beuipo, deixando, novamente, em aberto a questão do nome do rio e uma

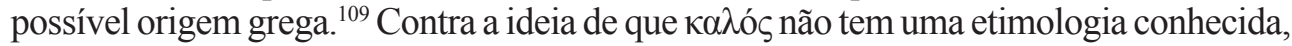
defendida por Chantraine, Bernal propôs uma origem semita para $* K a l$, o que poderia explicar o nome transmitido nos textos gregos. ${ }^{110}$ Recentemente, o achado e publicação de um grafito fenício num fragmento anfórico permite também pensar, com argumentos convincentes, que se trata de um topónimo, klpš, possivelmente relacionável com Calpe. ${ }^{111}$ Este nome, por sua vez, foi também associado a `A $\lambda \hat{\beta} \eta$ (cf. supra).

Nas margens do Guadalquivir, Ilipa surge como outro exemplo estimulante, uma vez que revela a dependência da leitura de um topónimo em relação aos mecanismos utilizados para "desmontá-lo" ( $i l+i p a$; $i l i+p a)$. Numa perspectiva basco-iberista, $\mathrm{Il}$ - seria uma formação ibérica que significava "cidade", o que seria redundante se aceitássemos a assinalada proposta de Untermann em relação aos nomes em -ip(p)o. ${ }^{112}$ Esta constatação foi

102 Villar 2000, 109. A este respeito, Torres $(2002,324)$ comentou que “(...) no se ve de forma clara como podría haber llegado desde Anatolia al suroeste peninsular, sobre todo, dado que no se han podido rastrear las etapas intermedias de la vía de difusión". Veja-se, não obstante, o mapa apresentado por Villar $(2000,111)$ no contexto desta temática. Para uma proposta de análise sobre os empréstimos linguísticos entre a Anatólia e as línguas semitas, nomeadamente o hebraico e o fenício, cf. Valério - Yakubovich 2010.

103 Villar 2000, 115.

104 Esta cronologia deveria ser definida no âmbito dos estudos linguísticos e, como isso não parece ser possível, pelo menos com o rigor exigível, não parece coerente preencher essa lacuna com vestígios arqueológicos. Isto não se aplica, porém, à discussão sobre a cronologia da escrita do Sudoeste, para a qual o registo arqueológico é de extrema importância (cf. supra, n. 24).

105 Rodríguez Adrados 2003, 46.

106 Villar 1999, 715; García Moreno 2001, 162.

107 Correa 1982 e 2011; Faria 1989; Villar 2000, 90-91.

108 Ptol. Geog. 2.5.3; Marcian. Peripl. 2.13.

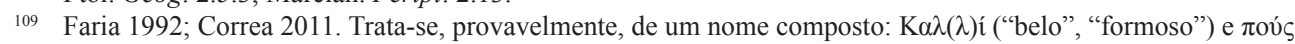

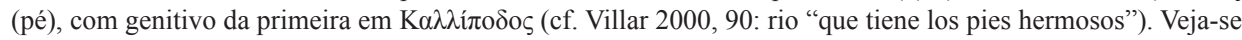
também a já citada passagem de Arist. Int. 16a 19-21, na qual o autor discute a falta de significado do termo.

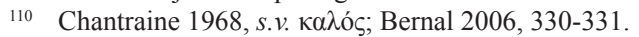

111 Zamora 2014, passim.

112 A presença de -il nos topónimos peninsulares foi também interpretada por García Moreno (2001, 164-165) como a referência a uma linha de água. Por seu turno, a raiz *Baes/*Bas, presente em topónimos como Baesippo, Basilippo ou Baesuris, pode ser relacionada com o teónimo Bes, cultuado na "ibéria púnica” (García Mo- 
suficiente para afastar Ilipa desta série, criando condições para propostas sobre alterações a partir de um topónimo original, ou mesmo sobre a formação de um híbrido "iberoturdetano". ${ }^{113}$ Devemos, porém, considerar que este nome foi também transmitido tardiamente.

\section{Discussão: toponímia e registo arqueológico}

Recentemente, a leitura e interpretação do chamado Papiro de Artemidoro lançou um interessante debate sobre uma aparente mudança de topónimo, que exemplifica algumas limitações da investigação face às fontes escritas, bem como à cronologia

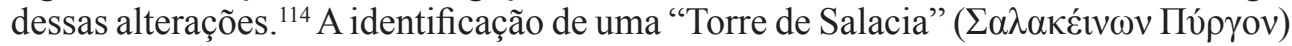
no texto colocou, desde o primeiro momento, sérias dúvidas em relação à ideia de que Imperatoria Salacia só tinha surgido em 45-44 a.C., remetendo a origem do nome para c. 104-101 a.C., e lançando, com isto, uma possível luz sobre a interpretação de uma passagem corrompida da Geografia de Estrabão. ${ }^{115}$ Pensou-se que o copista teria alterado o nome num momento do séc. I d.C., atendendo à cronologia proposta para o papiro. ${ }^{116}$ Esta discussão revela as dificuldades de interpretação dos processos subjacentes à formação, alteração ou substituição de um topónimo, mas, sobretudo, a incapacidade de recorrer a critérios arqueológicos para solucionar as dúvidas que, naturalmente, se colocam a tal situação.

Por outro lado, qualquer interpretação arqueológica que se baseie nestas leituras corre o risco de ser anacrónica e inadequada face à realidade histórica que pretende estudar, sobretudo se não considera os problemas que a toponímia coloca à investigação. Um desses problemas seria a diferença entre o ritmo de transformação das sociedades e o dos topónimos que, como sabemos, não é o mesmo. O registo arqueológico pode permitir o reconhecimento de processos de mudança social, económica, religiosa, etc. e datá-los com maior ou menor precisão, mas não dispõe de meios suficientes para apresentar a mesma leitura sobre testemunhos tardios que chegaram até nós através de algumas fontes escritas e de inscrições em numismas.

As recentes contribuições de Torres e de Almagro Gorbea recorrem, frequentemente, ao argumento linguístico para identificar o alcance da "colonização tartéssica”. ${ }^{117}$ Uma das áreas identificadas foi o interflúvio Sado-Tejo, onde duas ocupações partilham a desinência do topónimo: Beuipo e Olisipo. A identificação de influências "orientais", que reproduziam os padrões do Baixo Guadalquivir, em sítios "indíge-

reno 2001, n. 26). Assim, etnónimos como ilergetes (“os ribeirinhos”) ou bástulos relacionar-se-iam, respectivamente, com uma linha de água no primeiro caso, e com Bes no segundo.

113 Correa 2007; Villar 2000, 92-95; García Moreno 2001, 162-163. Para Villar, regista-se a intervenção de três línguas diferentes: "1) la lengua nativa preibérica responsable de *Ipa; 2) la lengua ibérica que generó el giro toponímico Il-ipa 'la ciudad de *Ipa', y que sin duda debió adaptar el topónimo en medida mayor o menor a sus hábitos lingüísticos; 3 ) el latín que tomó ya el giro en su integridad, interpretándolo como un simple topónimo, y adaptándolo en medida mayor o menor a sus propios hábitos" (Villar 2000, 94).

114 Gallazi et alii 2008.

115 Str. 3.3.1. Faria 2009. Na edição da Geografia estraboniana, de Müller, o hidrónimo, bem como Salacia, surgem

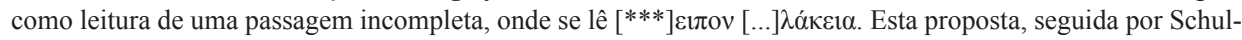
ten (1952: 196) e, com reservas, por Correa (1982, 73-74; Alarcão 2004, 319), resultaria no texto [***] ${ }^{*} 1 \pi$ ov [...]

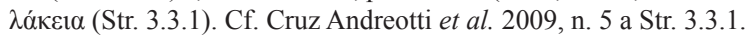

116 Faria 2009, 116-117; Alarcão 2010, 118; Albuquerque 2014, II, 62-68. Seria legítimo perguntar, neste contexto, se Artemidoro conhecia outro nome de Beuipo, transmitido por outro grupo ou por outra fonte do autor. Veja-se, neste sentido, o texto de Plin. HN 4.120, sobre as variações de um mesmo nome.

117 Torres 2002 e 2005; Almagro 2010; Almagro - Torres 2009. 
nas" (Alcácer, Setúbal e Lisboa), ${ }^{118}$ bem como de antropónimos e topónimos ditos "tartéssicos" que incidiam sobre zonas costeiras e portos de comércio, foram argumentos que concorreram, a par de outros, para a formulação desta hipótese. ${ }^{119}$ No entanto, não parece haver eco suficiente das reservas que são colocadas em relação à cronologia da formação destes topónimos e antropónimos, bem como à língua que lhes deu origem. ${ }^{120}$ Face a estas condições, é legítimo perguntar: estes conjuntos toponímicos podem ser utilizados como fontes históricas? Ou como indicadores étnicos seguros?

Estas contribuições são um resultado coerente (mas questionável) de alguns apriorismos sobre o concepção de "Tartessos" enquanto entidade indígena centrada no Baixo Guadalquivir e, a julgar pelas opiniões expostas, disseminada pelas vias de circulação para o interior na Vía de la Plata ${ }^{121}$ e pela costa atlântica portuguesa, que constituiriam uma periferia. ${ }^{122} \mathrm{O}$ próprio conceito de Tartessos, que, evidentemente, domina estas propostas, tem vindo a ser posto em causa, tanto no âmbito da sua construção arqueológica como na hermenêutica das fontes. ${ }^{123}$

No que diz respeito à imagem arqueológica de Tartessos como entidade indígena, parece hoje evidente que esta perspectiva apresenta inúmeras lacunas, entre elas a aceitação das informações escritas compiladas por Schulten e a convicção de que a Arqueologia acabaria por demonstrar que estes textos representavam a fase final de um processo que mergulhava as suas raízes no Bronze Final indígena. ${ }^{124} \mathrm{~A}$ homogeneidade que acabou por ser conferida ao conjunto de documentos que mencionam Tartessos só seria, neste sentido, compatível com uma visão essencialista dos processos históricos, revelando que, a priori, não se considerava a falta de relação entre a história de uma comunidade e as representações de observadores externos, ou mesmo as limitações destes textos. ${ }^{125}$

As análises dos textos e do registo arqueológico seguiram, inevitavelmente, caminhos diferentes, a tal ponto que raramente se vê, na actualidade, uma discussão sobre fontes escritas em publicações arqueológicas, mas tal não significa que exista uma inibição para o uso de uma entidade que foi mencionada nesses textos. Isto contribuiu para a perduração de ideias hoje ultrapassadas no âmbito da crítica textual, independentemente de todos os desenvolvimentos dos métodos de escavação e tratamento dos dados, ou mesmo do número de sítios actualmente conhecidos. ${ }^{126} \mathrm{~A}$ integração dos métodos da Nova Arqueologia a partir dos anos 70 levou a que se colocassem questões sobre o papel das elites (indígenas) e a considerar a sua intervenção como agentes activos nos processos de interacção. Antes disso, em 1968, Maluquer defendia que era necessário analisar Tartessos numa perspectiva social e económica em detrimento da definição da localização da cidade. ${ }^{127}$

\footnotetext{
118 A interpretação da sequência de ocupação de Alcácer do Sal (Beuipo) foi discutida em Albuquerque 2014, 329-330.

119 De Hoz 1989, 597-598; Torres 2005, 195; Almagro 2010.

120 De Hoz 1989, 598.

121 Almagro 2010; recentemente, Celestino - López-Ruiz 2016, 173 e ss.

122 Torres 2005; Almagro - Torres 2009.

123 Entre outros, Álvarez 2005; García Fernández 2012; Albuquerque 2013 e 2014.

124 Maluquer 1955. Schulten (1945) defendia que Tartessos acabara no séc. VI a.C. por obra dos cartagineses. Esta ideia manteve-se durante vários anos na investigação arqueológica (cf. Álvarez 2005 e 2010).

125 Álvarez 2005, 200 e ss; Albuquerque 2014, 135 e ss.

126 É de assinalar que em nenhum texto conhecido é possível afirmar que os "tartéssios" eram um grupo indígena diferente dos "fenícios" (Álvarez 2005, 200-201; contra, Celestino - López-Ruiz 2016, 24-124).

127 Maluquer 1969.
} 
A imagem de Tartessos passou, com isto, a basear-se em elementos que "encaixassem" na definição de "indígena tartéssico": localização interior, arquitectura oval ou circular, cerâmicas manuais que definiam realidades que se diferenciavam dos fenícios. Estes, por sua vez ocupavam a costa, construíam edifícios de planta rectangular ou quadrada e que utilizavam cerâmicas a torno. A toponímia encontra-se, precisamente, neste contexto, justificando a imagem que tem vindo a ser descrita ao longo deste trabalho, como representante de uma polarização que esteve na origem da própria designação de "tartéssica".

É pertinente questionar a importância da língua na construção de identidades colectivas na Península Ibérica proto-histórica, mas também na representação de outras comunidades nas fontes que deram a conhecer o nome de Tartessos. Não há informações directas que provem, cabalmente, que o idioma foi determinante para individualizar os "tartéssios" face a outras comunidades, exigindo, de futuro, uma cuidada análise que permita destacar a importância deste critério como elemento de representação nas fontes escritas mais antigas. Acrescentar-se-ia ainda o estudo de situações de interacção que se reflectiram no predomínio de uma língua sobre outra, ou mesmo na formação de idiomas "mistos", que podem não ser o reflexo exacto dos costumes. ${ }^{128}$ É também legítimo questionar até que ponto os topónimos podem ser fontes de interpretação de processos de transformação cultural, sobretudo com as limitações que se impõem à sua análise. ${ }^{129}$

É momento de terminar este texto com a questão que lhe deu título: A toponímia proto-histórica é, efectivamente, uma ferramenta do arqueólogo? A resposta a esta questão, de acordo com os argumentos expostos, é necessariamente negativa. $\mathrm{O}$ uso da toponímia para a análise do registo arqueológico só faz sentido em contextos nos quais há a firme convicção de que a uma cultura material corresponde um povo, e que a um povo corresponde a uma língua. Este princípio, é escusado justificá-lo com detalhe, é insuficiente, sobretudo quando a interpretação dessa cultura material está sujeita a vários apriorismos que foram assinalados em repetidas ocasiões. ${ }^{130}$ Nesses casos, podemos dizer que a resposta precede a pergunta, ou, dito de outro modo, as perguntas são formuladas para obter as respostas pretendidas.

A última afirmação é uma conclusão possível para o que vimos sobre a toponímia. Esta é justificada pela cultura material? Ou explica a cultura material? Nas perspectivas assinaladas, parece haver uma relação de reciprocidade, desenvolvida sobretudo na área da Arqueologia, sustentando argumentos que se enquadram nas interpretações propostas por alguns linguistas. Não parece cientificamente coerente, aos olhos de quem isto escreve, seleccionar uma hipótese de outra disciplina, despojá-la de todas as interrogações que ela coloca, e aplicá-la directamente a outro objecto de estudo com o estatuto de argumento de prova. Isto é ainda mais evidente quando se considera o lapso cronológico entre o período que se pretende analisar e a transmissão dos nomes, uma vez que resulta em anacronismos que não contribuem

128 A citada passagem de Salústio (Iug. 78) enquadra-se na primeira situação: refere os matrimónios contraídos entre Sidónios e Numidas em Leptis, que resultaram na utilização da língua dos segundos e dos costumes dos primeiros. Na segunda pode ser representada pelo texto de Hdt. 4.108.2, no qual o autor destaca a formação de uma língua "meio cita, meio grega", referindo-se aos contactos que os gregos mantiveram com os budinos no território destes últimos. São, somente, dois exemplos que requerem um estudo mais aprofundado, não só dos textos em si, mas também de outros casos.

129 Cf. Bühnen 1992, com uma comparação entre os topónimos germânicos e da Senegâmbia.

130 Entre outros, Álvarez 2005. 
nem para a interpretação etimológica, e muito menos para o conhecimento histórico ou arqueológico das comunidades da primeira metade do I milénio a.C.

Torna-se evidente que é necessário desenvolver, num futuro próximo, perspectivas que permitam construir um discurso histórico coerente em torno dos dados arqueológicos e linguísticos disponíveis para o estudo destas comunidades. Estes comentários procuram, portanto, incitar a um debate que só pode enriquecer o sentido crítico da investigação e a interacção entre disciplinas científicas que mantêm entre si (sobretudo quando os dados linguísticos são usados para sustentar a identificação de comunidades mencionadas nos textos da Antiguidade) uma relação problemática.

\section{Referências bibliográficas}

Alarcão, J. (2004): "Notas de arqueologia, epigrafia e toponímia - I", Revista Portuguesa de Arqueologia 7/1, 317-342.

Albertos Firmat, Ma L. (1966): La onomastica personal primitiva de Hispania: Tarraconense y Betica (=Theses et studia philologica Salmanticensia 13), Salamanca.

Albuquerque, $P$.

(2013): "Tartessos e Tartéssios, de Estesícoro a Éforo", [en] J. M. Arnaud - A. Martins C. Neves (eds.), Arqueologia em Portugal: 150 anos. Actas do I Congresso da Associação dos Arqueólogos Portugueses, Lisboa, 633-639.

(2014): Tartessos: a construção de identidades através do registo escrito e da documentação arqueológica. Um estudo comparativo. Dissertação de Doutoramento inédita, Universidade de Lisboa, 2 vols.

Almagro-Gorbea, M. (2010): "La colonización tartésica: toponimia y arqueología”, Palaeohispanica 10, 187-199.

Almagro-Gorbea, M. - Torres Ortiz, M. (2009): "La colonización de la costa atlántica de Portugal: ¿Fenicios o Tartesios?’, Acta Palaeohispanica X (=Palaeohispanica 9), 113142.

Álvarez Martí-Aguilar, M.

(2005): Tarteso. La construcción de un mito en la historiografía española, Málaga.

(2007): “Arganthonius Gaditanus. La identificación de Gadir y Tartessos en la tradición antigua", Klio 89/1, 477-492.

Arruda, A. M. (2001): “A Idade do Ferro Pós-orientalizante no Alentejo interior”, Revista Portuguesa de Arqueologia 4/2, 207-301.

Arteaga, O. - Schulz, H. - Roos, A. M. (1995): “El problema del ‘lacus Ligustinus'. Investigaciones geoarqueológicas en torno a las marismas del Guadalquivir", [en] VV.AA. 1995, 99-135.

Belén Deamos, Ma (1993): "Mil años de historia de Coria: la ciudad prerromana", Azotea 11-12, 35-60.

Belén Deamos, Ma - Escacena Carrasco, J. L. (1997): “Testimonios religiosos de la presencia fenicia en Andalucía Occidental", Spal 6, 103-131 (http://dx.doi.org/10.14198/ spal.1997.i6.07).

Bernal, M.

(1993): Atenea Negra. Las raíces afroasiáticas de la civilización clásica. I - La invención de la Antigua Grecia, 1785-1985, Barcelona.

(2006): Black Athena: The Afroasian Roots of Classical Civilization. III - The Linguistic Evidence, New Jersey. 
Bühnen, S. (1992): "Place names as an historical source: an introduction with examples from Southern Senegambia and Germany", History in Africa 19, 45-101. (https://doi.org/ 10.2307/3171995)

Celestino Pérez, S. - López-Ruiz, C. (2015): Tartessos and the Phoenicians in Iberia, Oxford. Chantraine, P. (1968): Dictionnaire étimologique de la langue grecque. Histoire des mots, Paris.

Corominas, J. (1990): Breve diccionario etimológico de la lengua castellana, Madrid.

Correa, J. A.

(1982): "La singularidad del letrero indígena en las monedas de Salacia", Numisma 177179, 69-74.

(1989): "El origen de la escritura paleohispánica", [en] J. González (ed.), Estudios sobre Urso. Colonia Iulia Genetiva (=Colección Alfar Universidad. Serie Investigación y Ensayo 45), Sevilla, 282-301.

(1996): "El pueblo de las estelas: un problema epigráfico-lingüístico", Estudios de Lenguas y Epigrafia Antiguas 2, 233-250.

(2000): "El topónimo Hispal(is)", Philologia Hispalensis 14, 181-190.

(2005): "Escritura tartésica”, [en] G. Carrasco Serrano - J. C. Oliva Mompeán (coords.), Escrituras y lenguas del Mediterráneo en la Antigüedad (=Universidad de Castilla-La Mancha. Humanidades 82), Cuenca, 289-305.

(2007): "El topónimo Ilipa y la inscripción indígena de Alcalá del Río", [en] E. Ferrer Albelda - A. Fernández Flores - J. L. Escacena Carrasco - A. Rodríguez Azogue (eds.), Ilipa Antiqva: de la Prehistoria a la época romana, Alcalá del Río, 93-101.

(2009): "Reflexiones sobre la lengua de las inscripciones en escritura del suroeste o tartesia", Palaeohispanica 9, 295-307.

(2011): "La leyenda indígena de las monedas de Salacia y el grafito de Abul (Alcácer do Sal, Setúbal)", [en] J. L. Cardoso - M. Almagro-Gorbea (eds.), Lucius Cornelius Bocchus: escritor da Idade de Prata da literatura latina, Lisboa, 103-112.

(2016): Toponimia antigua de Andalucía (=Universidad de Sevilla. Serie Lingüística 46), Sevilla.

Cruz Andreotti, G. - García Quintela, M. V. - Gómez Espelosín, F. J. (2009): Estrabón. Geografia de Iberia, Madrid.

Cunchillos Ilarri, J. L. (2000): "Nueva etimología de la palabra 'Hispania"”, [en] Ma E. Aubet - M. Barthélemy (eds.), Actas del IV Congreso Internacional de estudios fenicios y púnicos. Cádiz, 2 al 6 de octubre de 1995, Cádiz, vol. 1, 217-225.

De Hoz, J.

(1989): "El desarrollo de la escritura y las lenguas de la zona meridional", [en] Ma E. Aubet (coord.), Tartessos: Arqueología protohistórica del bajo Guadalquivir, Sabadell, 523-587.

(1995): “Tartesio, fenicio y céltico 25 años después”, [en] VV.AA. 1995, 591-605.

(1996): "El origen de las escrituras paleohispánicas quince años después", [en] F. Villar - J. d'Encarnação (eds.), La Hispania Prerromana. Actas del VI Coloquio sobre lenguas y culturas prerromanas de la Península Ibérica (Coimbra 1994), (=Universidad de Salamanca. Acta Salmanticensia, Estudios Filológicos 262), Salamanca, 171-206.

(2013): "Wilhelm von Humboldt y las lenguas paleo-hispánicas", [en] D. Marzoli - J. Maier - T. G. Schattner (eds.), Historia del Instituto Arqueológico Alemán de Madrid. I - Antecedentes y fundación del Departamento de Madrid, Mainz, 127-139.

Díaz Tejera, A. (1982): Sevilla en los textos clásicos greco-latinos (=Biblioteca de temas sevillanos 20), Sevilla. 
Escacena Carrasco, J. L.

(1992): “Indicadores étnicos en la Andalucía prerromana", Spal 1, 321-344 (http://dx.doi. org/10.12795/spal.1992.i1.16).

(2001): "Fenicios a las puertas de Tartessos", Complutum 12, 73-96 (http://dx.doi. org/10.5209/CMPL.30845).

Faria, A. M.

(1989): “A numária de *Cantnipo", Conimbriga 28, 71-99.

(1992): “Ainda sobre o nome pré-romano de Alcácer do Sal”, Vipasca 1, 39-48.

(2009): “Artemidoro entre os Salakeinoi?”, Revista Portuguesa de Arqueologia 12/1, $115-125$.

Faust, M. (1976): “Cuestiones generales de toponimia prerromana”, [en] F. Jordá - J. de Hoz - L. Michelena (eds.), Actas del I Coloquio sobre Lenguas y culturas prerromanas de la Península Ibérica (Salamanca 1974), Salamanca, 165-189.

Fernández Götz, M. A. (2007): “¿'Celtas’ en Andalucía? Mirada historiográfica sobre una problemática (casi) olvidada”, Spal 16, 173-185 (http://dx.doi.org/10.12795/spal.2007. i16.08).

Ferrer Albelda, E. - Jiménez Delgado, J. M. (2015): “Kalathê/ Kaláthousa. Una ciudad ignota del Extremo Occidente”, [en] J. García Sánchez - I. Mañas Romero - F. Salcedo Garcés (eds.), "Navigare necesse est": estudios en homenaje al profesor José María Luzón Nogué, Madrid, 144-150.

Gallazi, C. - Kramer, B. - Settis, S. (2008): Il Papiro di Artemidoro (P. Artemid.), Milano.

Gangutia Elícegui, E. (1999): "Hecateo y las inscripciones griegas más antiguas de la Península Ibérica", Archivo Español de Arqueología 72, 3-14. (https://doi.org/10.3989/aespa.1999.v72.292)

García Alonso, J. L. (1996): "Nombres griegos en -oussa en el Mediterráneo occidental: análisis lingüístico e histórico", Complutum 7, 105-124.

García Fernández, F. J. (2012): “Tartesios, túrdulos, turdetanos. Realidad y ficción de la homogeneidad étnica de la Bética Romana", [en] J. Santos Yanguas - G. Cruz Andreotti (eds.), Romanización, fronteras y etnias en la Roma Antigua: el caso hispano (=Anejos de Veleia. Acta 12. Revisiones de Historia Antigua VII), Vitoria-Gasteiz, 691-734.

García Fernández, F. J. - Fernández Götz, M. A. (2010): “Esencialismo, normativismo, posmodernismo: las interpretaciones sobre la etnicidad en la Arqueología española", Gerión 28/2, 53-84 (http://dx.doi.org/10.5209/GERI.36353).

García Moreno, L. A.

(1989): "La Hispania anterior a nuestra era: verdad, ficción y prejuicio en la historiografía antigua y moderna", [en] Actas del VII Congreso Español de Estudios Clásicos. Madrid, 20-24 de abril de 1987, Madrid, vol. III, 17-43.

(2001): "Los topónimos en -ippo. Una reflexión etnográfica", [en] F. Villar - P. Fernández Álvarez (eds.), Religión, lengua y cultura prerromana de Hispania. Actas del VIII Coloquio sobre lenguas y culturas prerromanas de la Península Ibérica (Salamanca 1999), (=Universidad de Salamanca. Acta Salmanticensia, Estudios Filológicos 283), Salamanca, 161-168.

García y Bellido, A. (1948): Hispania Graeca, Barcelona, 3 vols.

Guerra, A.

(1995): Plínio - o - Velho e a Lusitânia, Lisboa.

(2010): “Algumas observações sobre a Escrita do Sudoeste", Xelb 4, 103-114.

Hubschmid, J. (1960): “Toponimia Prerromana”, [en] M. Alvar - A. Badía - R. Balbín - L. F. Lidley Cintra (eds.), Enciclopedia Lingüistica Hispánica. I - Antecedentes. Onomástica, Madrid, 447-493. 
Humboldt, W. von (1866): Recherches sur les habitants primitifs de l'Espagne a l'aide de la langue basque, Paris.

Koch, J. T.

(2009): “A case for Tartessian as a Celtic Language", Acta Palaeohispanica X (=Palaeohispanica 9), 339-351.

(2010), "Paradigm shift? Interpreting Tartessian as Celtic", [en] B. Cunliffe - J. T. Koch (eds.), Celtic from the West. Alternative perspectives from Archaeology, Genetics, Language and Literature, Oxford, 185-301.

Lipínski, E. (1984): "Vestiges phéniciens d'Andalousie", Orientalia Louvaniensia Periodica $15,81-132$.

Machado, J. P. (1977): Dicionário Etimológico da Língua Portuguesa, Lisboa.

Maia, Ma G. P. - Silva, L. F. (2004): “Culto de Baal em Tavira”, Huelva Arqueológica 20, 171-194.

Maluquer de Motes, J.

(1955): "El proceso histórico de las primitivas poblaciones peninsulares II", Zephyrvs 6, 241-283.

(1969): “Introducción al problema de Tartessos", [en] VV.AA. 1969, 1-6.

Mangas, J. - Plácido, D. (eds.), (1998): Testimonia Hispania Antiqua. IIA. La Península Ibérica en los autores griegos: de Homero a Platón", Madrid (edición, traducción y comentario de E. Gangutia Elícegui).

Mantas, V. G. (1997): “As Civitates: esboço da geografia política e económica do Algarve romano", [en] R. Parreira - M F F. Barata - A. L. Santos (eds.), Noventa séculos entre a serra e o mar, Lisboa, 283-310.

Marek, C. (2004): "Halys", [en] H. Cancik - H. Schneider (eds.), Brill's New Pauly. Encyclopaedia of the Ancient World, Leiden, vol. 4, 1120.

Mayet, F. - da Silva, C. T. (2000): L'établissement phénicien d'Abul. Portugal. Comptoir et Sanctuaire, Paris.

Moret, P. (2006): “La formation d'une toponymie et d'une ethnonymie grecques de l'Ibérie: étapes et acteurs", [en] G. Cruz Andreotti - P. Le Roux - P. Moret (eds.), La invención de una geografía de la Península Ibérica. I - La época republicana, Málaga-Madrid, 39-76.

Mota, A. T. da (1950): Topónimos de origem portuguesa na costa ocidental de África. Desde o Cabo Bojador ao Cabo de Santa Catarina, Bissau.

Na'aman, N. (1999): “Baal toponyms; Baal-Hamon; Baar-Hermon; Baal-Meon”, [en] van der Toorn et alii (eds.), 1999, 140-147.

Padilla Monge, A. (1993): “Caura: el topónimo”, Azotea 11, 63 - 64.

Pellegrin, A. (1949): Essai sur les noms de lieux d'Algérie et de Tunisie: Etymologie, signification, Tunis.

Pritchard, J. B. (1969): Ancient Near Eastern texts relating to the Old Testament, Princeton, New Jersey.

Rodríguez Adrados, F. (2000): “Topónimos griegos en Iberia y Tartessos”, Emerita 68/1, 1-18.

(2001): "Más sobre Iberia y los topónimos griegos", Archivo Español de Arqueología 74, 25-33 (https://doi.org/10.3989/aespa.2001.v74.145).

(2002): "Hacia una teoría de la ciencia toponímica", Revista Española de Lingüística 32/1, 33-51.

Röllig, W. (1999): “Baal - Shamem”, [en] van der Toorn et alii (eds.), 1999, 149-151. 
Sanmartín, J. (1994): “Toponimia y antroponimia: Fuentes para el estudio de la cultura púnica en España", [en] J. L. Cunchillos Ilarri - M. Molin Matos (coords.), El mundo púnico. Historia, sociedad y cultura, Murcia, 227-247.

Schulten, A.

(1945): Tartessos, Madrid (2 ${ }^{\mathrm{a}}$ ed.).

(1952): Fontes Hispaniae Antiquae. Vol. 6, Geografia de Iberia: Estrabón, Barcelona.

Serra, G. (1955): “Antichi rapporti della Sardegna col mondo mediterraneo”, [en] A. Badía - A. Griera - F. Udina (eds.), VII Congreso Internacional de Lingüística Románica. Universidad de Barcelona, 7 - 10 abril 1953. II - Actas y memorias, Barcelona, 811821.

Sznycer, M. (2000): “Appendice II. Note sur les graffites phéniciens d'Abul”, [en] Mayet da Silva 2000, 261-264.

Torres Ortiz, M.

(2002): Tartessos (=Real Academia de la Historia. Publicaciones del Gabinete de Antigüedades. Bibliotheca Archaeologica Hispana 14; Studia Hispano-Phoenicia 1), Madrid.

(2005): “¿Una colonización tartésica en el interfluvio Tajo-Sado en la Primera Edad del Hierro?", Revista Portuguesa de Arqueologia 8/2, 193-213.

Tovar, A.

(1969): "El oscuro problema de la lengua de los tartesios", [en] VV.AA. 1969, 341-346.

(1970): "Hidronímica europea antigua: Jarama, Balsa", Habis 1, 5-9.

(1985-1986): "Lenguas y pueblos de la antigua Hispania: lo que sabemos de nuestros antepasados protohistóricos", Veleia 2-3, 15-34.

Untermann, J. (1962): “Áreas e movimentos linguísticos na Hispânia pré-romana”, Revista de Guimarães 72/1-2, 5-41.

Valério, M. (2014): "The Interpretative Limits of the Southwestern Script", Journal of Indoeuropean Studies 42/3-4, 439-467.

Valério, M. - Yabukovich. I. (2010): “Semitic Word for 'Iron' as Anatolian Loanword”, [en] T. M. Nikolaev (ed.), Исследования по Лингвистике и Семиотике Сборник статей к юбилею Вяч. Вс. Иванова (Studies in Linguistics and Semiotics: A Collection of Articles for the Anniversary for Vyacheslav V. Ivanov), Moscow, 108-116.

van der Toorn, K. - Becking, B. - van der Hoorst, P. (eds.), (1999): Dictionary of Deities and Demons in the Bible, Leiden.

Villar, F.

(1999): "Los topónimos meridionales de la serie ipo", [en] F. Beltrán Lloris - F. Villar (eds.), Pueblos, lenguas y escrituras en la Hispania prerromana: Actas del VII Coloquio sobre Lenguas y Culturas Paleohispánicas (Zaragoza, 12 a 15 de marzo de 1997), (=Universidad de Salamanca. Acta Salmanticensia, Estudios Filológicos 273), Salamanca, 685718.

(2000): Indoeuropeos y no indoeuropeos en la Hispania Prerromana (=Universidad de Salamanca. Acta Salmanticensia, Estudios Filológicos 277), Salamanca.

(2014): Indoeuropeos, íberos, vascos y sus parientes: estratigrafía y cronología de las poblaciones prehistóricas (=Universidad de Salamanca. Acta Salmanticensia, Estudios Filológicos 340), Salamanca.

VV.AA.

(1969): Tartessos y sus problemas: V Symposium Internacional de Prehistoria peninsular. Jerez de la Frontera, septiembre de 1968 (=Universidad de Barcelona, Instituto de Arqueología y Prehistoria. Publicaciones Eventuales 13), Barcelona. 
(1995): Tartessos 25 años después (1968-1993). Actas del Congreso Conmemorativo del V Symposium Internacional de Prehistoria Peninsular (=Serie Biblioteca de Urbanismo y Cultura 14), Jerez de la Frontera.

West, M. L. (1988): “The Rise of the Greek Epic", Journal of Hellenic Studies 108, 151-172 (http://dx.doi.org/10.2307/632637).

Wikander, S. (1966): "Sur la langue des inscriptions sud-hispaniques", Studia Linguistica 20/1, 1-8 (http://dx.doi.org/10.1111/j.1467-9582.1966.tb00530.x).

Willcock, M. M. (1970): A commentary on Homer's Iliad, Books I-VI, London.

Zamora López, A. (2014): "Palabras fluidas en el extremo Occidente: Sobre un nuevo grafito fenicio, hallado en la desembocadura del Tajo", [en] P. Bádenas de la Peña et alii (eds.), Homenaje a Ricardo Olmos. Per speculum in aenigmate. Miradas sobre la Antigüedad (=Anejos de Erytheia. Estudios y Textos 7), Madrid, 306-314. 
